\title{
Biofield Energy Healing Based Vitamin D3: An Improved Overall Bone Health Activity in MG-63 Cell Line
}

\author{
Karen Byrnes Allen', Mahendra Kumar Trivedi ${ }^{*}$, Alice Branton ${ }^{1}$, Dahryn Trivedi' ${ }^{1}$, Gopal Nayak ${ }^{1}$, Mayank \\ Gangwar $^{2}$ and Snehasis Jana ${ }^{2 *}$ \\ ${ }^{1}$ Trivedi Global Inc., USA
}

${ }^{2}$ Trivedi Science Research Laboratory Pvt. Ltd., India

Submission: April 23, 2018; Published: May 18, 2018

*Corresponding author: Mahendra Kumar, Trivedi Global, Inc., Henderson, USA, Email: publication@trivedisrl.com

\begin{abstract}
The potential of The Trivedi Effect ${ }^{\circledR}$-Consciousness Energy Healing vitamin D3 and DMEM medium was investigated in human bone osteosarcoma cells (MG-63). The Test Items (TI) i.e. vitamin $\mathrm{D}_{3}$ and DMEM were separated into two parts. Bone health parameters were tested such as Alkaline Phosphatase enzyme (ALP) activity, collagen levels and bone mineralization. The Test Items (TI) i.e. vitamin D3 and DMEM medium were divided into two parts. The test samples received Consciousness Energy Healing Treatment by Karen Byrnes Allen and samples were defined as the Biofield Energy Treated (BT) samples, while the other parts of each sample were denoted as the Untreated test items (UT). Cell viability using MTT assay exhibited increased cell viability more than 71\% with safe and nontoxic profile among test samples on MG-63 cell line. The level of ALP was significantly increased by $116.4 \%$ at $50 \mu \mathrm{g} / \mathrm{mL}$ in the UT-DMEM+BT-TI group, while $35.6 \%, 81.2 \%$, and $47.9 \%$ at 10,50 and $100 \mu \mathrm{g} / \mathrm{mL}$, respectively in the BT-DMEM+UT-TI group. In addition, ALP level was increased by $42.3 \%$ and $90.6 \%$ at 10 and $50 \mu \mathrm{g} /$ $\mathrm{mL}$, respectively in the BT-DMEM+BT-TI groups as compared with the untreated group. The level of collagen was significantly increased by $10.5 \%$ and $110.1 \%$ at 0.1 and $1 \mu \mathrm{g} / \mathrm{mL}$, respectively in the UT-DMEM+BT-TI group, while $22.6 \%$ and $190.6 \%$ at $0.1 \mathrm{and} 1 \mu \mathrm{g} / \mathrm{mL}$, respectively in the BT-DMEM+UT-TI group as compared with the untreated group. In addition, BT-DMEM+BT-TI group showed a significant increased collagen level by $140.6 \%$ and $39.9 \%$ at 0.1 and $1 \mu \mathrm{g} / \mathrm{mL}$, respectively as compared with the untreated test item and DMEM group. The percent of bone mineralization was significantly increased by $128.7 \%$ at $50 \mu \mathrm{g} / \mathrm{mL}$, in the UT-DMEM+BT-TI group, while $34.1 \%, 154.7 \%$, and $18.7 \%$ at 1,10 , and $50 \mu \mathrm{g} / \mathrm{mL}$, respectively in the BT-DMEM+UT-TI group as compared with the untreated group. In addition, BT-DMEM+BT-TI group showed a significant increased bone mineralization by $105.7 \%, 78.1 \%$, and $39.6 \%$ at 1,10 , and $50 \mu \mathrm{g} / \mathrm{mL}$, respectively as compared with the untreated group. Thus, the study results concluded that The Trivedi Effect ${ }^{\circledR}$ Treatment would be the best alternative treatment for the maintenance of strong and healthy bones and quality of life. Further, it regulates the osteoblast function and improved the level of collagen, ALP, and calcium absorption in wide range of bone disorders along with wide range of adverse bone health conditions.
\end{abstract}

Keywords: The Trivedi Effect ${ }^{\circledR}$; Bone Health; Biofield Healing; Osteosarcoma Cells; Vitamin D; Bone mineralization

Abbreviations: CAM: Complementary and Alternative Medicine, NCCAM: National Center for Complementary and Alternative Medicine; MG63: Human Bone Osteosarcoma Cells, ALP: Alkaline phosphatase, DMEM: Dulbecco's Modified Eagle's Medium; FBS: Fetal bovine serum; EDTA: Ethylene Diamine Tetra Acetic Acid, UT: Untreated, BT: Biofield Energy Treated, TI: Test Item.

\section{Introduction}

Vitamin D has multiple effects which regulate the functions in different organs such as brain, lungs, liver, kidneys, and heart, immune, skeletal, and reproductive systems. Moreover, it has significant anti-inflammatory, anti-arthritic, anti-osteoporosis, anti-stress, anti-aging, anti-apoptotic, wound healing, anti-cancer, anti-psychotic, and anti-fibrotic roles. Vitamin D receptors (VDRs) are widely present in most of the body organs like brain, heart, lungs, kidney, liver, pancreas, large and small intestines, muscles, reproductive, nervous system, etc. [1]. VDRs influence cell-tocell communication, normal cell growth, cell differentiation, cell cycling and proliferation, hormonal balance, neurotransmission, skin health, immune and cardiovascular functions. Bone-related health issues become a major problem among the population from village to the cities. Vitamin D plays a vital role in preserving a healthy mineralized skeleton of most of the vertebrates including humans. Cod liver oil, irradiation of other foods including plants, sunlight, etc. are found to be effective against bone related disorders, which lead to discovering the active principle- vitamin D [1]. The role of vitamin $\mathrm{D}$ has been well defined not only for improving the bone mineralization but also with increased bone resorption, aging, inflammation and overall quality of life. Vitamin $\mathrm{D}_{3}$ is synthesized in the skin by sunlight and once formed it sequentially metabolized in the liver and kidney to 1,25-dihydroxyvitamin D (calcitriol, the vitamin D hormone) [2]. Calcitriol play an import- 
ant role in maintaining the normal level of calcium and phosphorus, promotes bone mineralization, induce or repress the genes responsible for conserving the mineral homeostasis and skeletal integrity, and inhibit hypertension, kidney damage, cardiovascular and immune disorders (such as Lupus, Addison Disease, Graves' Disease, Hashimoto Thyroiditis, Multiple Sclerosis, Myasthenia Gravis, Anemia, Sjogren Syndrome, Systemic Lupus Erythematosus, Diabetes, Alopecia Areata, Fibromyalgia, Vitiligo, Psoriasis, Scleroderma, Chronic Fatigue Syndrome and Vasculitis), and the secondary hyperparathyroidism [3]. Vitamin D insufficiency and deficiency is the major health problem, which causes metabolic bone disease in the young and elderly populations [4]. Fortified foods have a variable amount of vitamin D and most of the foods do not contain vitamin D, which can be fulfilled using some supplements. In order to avoid the bone related disorders such as osteomalacia, exacerbate osteoporosis, hyperparathyroidism, immune disorders, etc. calcium 1000-1500mg/day along with vitamin D supplement around $400 \mathrm{IU} /$ day is very important for maintaining the good bone health [5].

Various in vitro studies have readily established the role of bone health using cell lines and its resorbing effects using three important key biomarkers, such as alkaline phosphatase (ALP), collagen and calcium. MG-63 cell line derived from juxta cortical osteosarcoma, which represents an immature osteoblast phenotype and undergoes temporal development in long term culture. The response of MG-63 cells to 1,25-dihydroxyvitamin $D_{3}$ $\left(1,25(\mathrm{OH})_{2} \mathrm{D}_{3}\right)$ administration has been studied to be similar to normal human osteoblast cells [6]. Hence, MG-63 cell line is widely used for studying the potential of any test compounds to improve the bone health [7]. The formation of new bone involves a complex series of events including the proliferation and differentiation of osteoblasts, and eventually the formation of a mineralized extracellular matrix. ALP is a phenotypic marker for the early differentiation and maturation of osteoblasts. ALP increases the local concentration of inorganic phosphate for bone mineralization and hence is an important marker for osteogenic activity [8]. Similarly, active osteoblasts synthesize and extrude collagen, which plays an important role in the formation of bone extracellular matrix by providing strength and flexibility. Collagen fibrils formed an arrays of an organic matrix known as Osteoid [9]. Likewise, calcium phosphate is deposited in the Osteoid and gets mineralized (combination of calcium phosphate and hydroxyapatite) and provides rigidity to the bone [10]. Thus, these parameters are very essential in order to study the bone health in cell lines. Authors evaluated the in vitro effect of the Biofield Energy Treated vitamin $\mathrm{D}_{3}$ as a test item, a Complementary and Alternative Medicine (CAM) on bone health using MG-63 cell line for major biomarkers.

Within the burgeoning ground of CAM therapies, Biofield Energy Treatment or energy medicine, is emerging with significant benefits in various scientific fields. The effects of the CAM therapies have great potential, which include external qigong, Johrei, Reiki, therapeutic touch, yoga, Qi Gong, polarity therapy, Tai Chi, pranic healing, deep breathing, chiropractic/osteopathic manipulation, guided imagery, meditation, massage, homeopathy, hypnotherapy, progressive relaxation, acupressure, acupuncture, special diets, relaxation techniques, Rolfing structural integration, healing touch, movement therapy, pilates, mindfulness, Ayurvedic medicine, traditional Chinese herbs and medicines in biological systems both in vitro and in vivo[11]. Biofield Energy Healing Treatment (The Trivedi Effect ${ }^{\circledR}$ ) contain a putative bioenergy, which is channeled by a renowned practitioners from a distance. Biofield Energy Healing as a CAM showed a significant results in biological studies [12]. However, the National Center for Complementary and Alternative Medicine (NCCAM), well-defined Biofield therapies in the subcategory of Energy Therapies [13]. The Trivedi Effect ${ }^{\circledR}$ Consciousness Energy Healing Treatment has been reported with significant revolution in the physicochemical properties of metals, chemicals, ceramics and polymers [14-16], improved agricultural crop yield, productivity, and quality $[17,18]$, transformed antimicrobial characteristics $[19,20]$, bone health $[21,22]$, biotechnology [23], improved bioavailability [24-26], skin health [27,28], nutraceuticals $[29,30]$, cancer research [31,32], and human health and wellness.

Based on the significant outcomes of Biofield Energy Treatment and vital role of vitamin $\mathrm{D}_{3}$ on bone health, authors sought to evaluate the impact of the Biofield Energy Treatment (The Trivedi Effect ${ }^{\circledR}$ ) on vitamin $D_{3}$ as test sample for bone health activity with respect to the assessment of different bone health parameters like ALP, collagen content, and bone mineralization using standard in vitro assays in MG-63 cells.

\section{Material and Methods \\ Chemicals and reagents}

Rutin hydrate was purchased from TCI, Japan, while vitamin $D_{3}$ (denoted as test item) and L-ascorbic acid were obtained from Sigma-Aldrich, USA. Fetal Bovine Serum (FBS) and Dulbecco's Modified Eagle's Medium (DMEM) were purchased from Life Technology, USA. Antibiotics solution (penicillin-streptomycin) was procured from HiMedia, India, while 3-(4, 5-diamethyl-2-thiazolyl)-2, 5-diphenyl-2H-tetrazolium) (MTT), Direct Red 80, and ethylene diamine tetra acetic acid (EDTA) were purchased from Sigma, USA. All the other chemicals used in this experiment were analytical grade procured from India.

\section{Cell culture}

Human bone osteosarcoma cell line -MG-63 was used as test system in the present study. The MG-63 cell line was maintained in DMEM growth medium for routine culture supplemented with $10 \%$ FBS. Growth conditions were maintained as $37{ }^{\circ} \mathrm{C}, 5 \% \mathrm{CO}_{2}$ and $95 \%$ humidity and sub cultured by trypsinisation followed by splitting the cell suspension into fresh flasks and supplementing with fresh cell growth medium. Three days before the start of the experiment, the growth medium of near-confluent cells was replaced with fresh phenol-free DMEM, supplemented with $10 \%$ 
charcoal dextran stripped FBS (CD-FBS) and 1\% penicillin-streptomycin [33].

\section{Experimental design}

The experimental groups consisted of cells in baseline control, vehicle control groups (0.05\% DMSO with Biofield Energy Treated and untreated DMEM), positive control group (rutin hydrate) and experimental test groups. The experimental groups included the combination of the Biofield Energy Treated and untreated vitamin $\mathrm{D}_{3} /$ DMEM. It consisted of four major treatment groups on specified cells with Untreated-DMEM + Untreated-Test item (UT-TI), UT-DMEM + Biofield Energy Treated test item (BT-TI), BT-DMEM + UT-TI, and BT-DMEM + BT-TI.

\section{Consciousness energy healing treatment strategies}

The test item and DMEM were divided into two parts. One part each of the test item and DMEM was treated with the Biofield Energy by a renowned Biofield Energy Healer (also known as The Trivedi Effect ${ }^{\circledR}$ ) and coded as the Biofield Energy Treated item, while the second part did not receive any sort of treatment. This Biofield Energy Healing Treatment was provided by Karen Byrnes Allen remotely for $\sim 5$ minutes. Biofield Energy Healer was remotely located in the USA, while the test samples were located in the research laboratory of Dabur Research Foundation, New Delhi, India. This Biofield Energy Treatment was administered for 5 minutes through the Healer's unique Energy Transmission process remotely to the test samples under laboratory conditions. Karen Byrnes Allen in this study never visited the laboratory in person, nor had any contact with the test item and medium. Further, the control group was treated with a sham healer for comparative purposes. The sham healer did not have any knowledge about the Biofield Energy Treatment. After that, the Biofield Energy Treated and untreated samples were kept in similar sealed conditions for experimental study.

\section{Determination of non-cytotoxic concentration}

The cell viability was performed by MTT assay in human bone osteosarcoma cell line (MG-63). The cells were counted and plated in 96 well plates at the density corresponding to $5 \mathrm{X} 10^{3}$ to 10 $\mathrm{X} 10^{3}$ cells/well/180 $\mu \mathrm{L}$ of cell growth medium. The above cells were incubated overnight under growth conditions and allowed the cell recovery and exponential growth, which were subjected to serum stripping or starvation. The cells were treated with the test item, DMEM, and positive control. The untreated cells were served as baseline control. The cells in the above plate(s) were incubated for a time point ranging from 24 to 72 hours in $\mathrm{CO}_{2}$ incubator at $37{ }^{\circ} \mathrm{C}, 5 \% \mathrm{CO}_{2}$, and $95 \%$ humidity. Following incubation, the plates were taken out and $20 \mu \mathrm{L}$ of $5 \mathrm{mg} / \mathrm{mL}$ of MTT solution were added to all the wells followed by additional incubation for 3 hours at $37^{\circ} \mathrm{C}$. The supernatant was aspirated and $150 \mu \mathrm{L}$ of DMSO was added to each well to dissolve formazan crystals. The absorbance of each well was read at $540 \mathrm{~nm}$ using Synergy HT micro plate reader, BioTek, USA [34]. The percentage cytotoxicity at each tested concentrations of the test substance were calculated using the following equation (1):

$$
\% \text { Cytotoxicity }=(1-X / R) * 100
$$

Where, $\mathrm{X}=$ Absorbance of treated cells; $\mathrm{R}=$ Absorbance of untreated cells

The percentage cell viability corresponding to each treatment was obtained using the following equation (2):

$$
\% \text { Cell Viability }=100-\% \text { Cytotoxicity }
$$

The concentrations exhibiting $\geq 70 \%$ Cell viability was considered as non-cytotoxic.

\section{Assessment of alkaline phosphatase (ALP) activity}

The cells were counted using an hemocytometer and plated in a 24 -well plate at the density corresponding $1 \times 10^{4}$ cells/well in phenol free DMEM supplemented with $10 \%$ CD-FBS. Following respective treatments, the cells in the above plate were incubated for 48 hours in $\mathrm{CO}_{2}$ incubator at $37{ }^{\circ} \mathrm{C}, 5 \% \mathrm{CO}_{2}$, and $95 \%$ humidity. After 48 hours of incubation, the plate was taken out and processed for the measurement of ALP enzyme activity. The cells were washed with $1 \mathrm{X}$ PBS and lysed by freeze thaw method i.e., incubation at $-80^{\circ} \mathrm{C}$ for 20 minutes followed by incubation at 37 ${ }^{\circ} \mathrm{C}$ for 10 minutes. To the lysed cells, $50 \mu \mathrm{L}$ of substrate solution i.e., $5 \mathrm{mM}$ of $p$-nitrophenyl phosphate ( $p \mathrm{NPP}$ ) in $1 \mathrm{M}$ diethanolamine and $0.24 \mathrm{mM}$ magnesium chloride $\left(\mathrm{MgCl}_{2}\right)$ solution ( $\mathrm{pH} 10.4$ ) was added to all the wells followed by incubation for 1 hour at $37^{\circ} \mathrm{C}$. The absorbance of the above solution was read at $405 \mathrm{~nm}$ using Synergy HT micro plate reader (Biotek, USA). The absorbance values obtained were normalized with substrate blank ( $p$ NPP solution alone) absorbance values [33]. The percentage increase in ALP enzyme activity with respect to the untreated cells (baseline group) was calculated using equation (3):

$$
\% \text { Increase }=[(X-R) / R)] * 100
$$

Where, $\mathrm{X}=$ Absorbance of cells corresponding to positive control and test groups

$\mathrm{R}=$ Absorbance of cells corresponding to baseline group (untreated cells).

\section{Assessment of collagen synthesis}

The MG-63 cells were counted using a hemocytometer and plated in 24-well plate at the density corresponding to $10 \times 10^{3}$ cells/well in phenol free DMEM supplemented with 10\% CD-FBS. Following respective treatments, the cells in the above plate were incubated for 48 hours in $\mathrm{CO}_{2}$ incubator at $37^{\circ} \mathrm{C}, 5 \% \mathrm{CO}_{2}$, and $95 \%$ humidity. After 48 hours of incubation, the plate was taken out and the amount of collagen accumulated in MG- 63 cells corresponding to each treatment was measured by Direct Sirius red dye binding assay. In brief, the cell layers were washed with PBS and fixed in Bouin's solution (5\% acetic acid, 9\% formaldehyde and $0.9 \%$ picric acid) for 1 hours at room temperature (RT). After 1 hour of incubation, the above wells were washed with milliQ water and air dried. The cells were then stained with Sirius red dye solution 
for 1 hour at RT followed by washing in $0.01 \mathrm{~N} \mathrm{HCl}$ to remove unbound dye. The collagen dye complex obtained in the above step was dissolved in $0.1 \mathrm{~N} \mathrm{NaOH}$ and absorbance was read at $540 \mathrm{~nm}$ using Biotek Synergy HT micro plate reader. The level of collagen was extrapolated using standard curve obtained from purified Calf Collagen Bornstein and Traub Type I (Sigma Type III) [33]. The percentage increase in collagen level with respect to the untreated cells (baseline group) was calculated using equation (4):

$$
\% \text { Increase }=[(X-R) / R] * 100
$$

Where, $\mathrm{X}=$ Collagen levels in cells corresponding to positive control and test groups

$\mathrm{R}=$ Collagen levels in cells corresponding to baseline group (untreated cells).

\section{Assessment of bone mineralization by alizarin red $S$ staining}

The MG-63 cells were counted using an hemocytometer and plated in 24-well plate at the density corresponding to 10 $\mathrm{x} 10^{3}$ cells/well in phenol free DMEM supplemented with $10 \%$ CDFBS. Following respective treatments, the cells in the above plate were incubated for 48 hours in $\mathrm{CO}_{2}$ incubator at $37^{\circ} \mathrm{C}, 5 \% \mathrm{CO}_{2}$, and $95 \%$ humidity to allow cell recovery and exponential growth. Following overnight incubation, the above cells will be subjected to serum stripping for 24 hours. The cells will be then be treated with non-cytotoxic concentrations of the test samples and positive control. After 3-7days of incubation with the test samples and positive control, the plates were taken out cell layers and processed further for staining with Alizarin Red S dye. The cells were fixed in 70\% ethanol for 1 hour, after which Alizarin Red solution (40 $\mu \mathrm{m}$; pH 4.2) was added to the samples for 20 minutes with shaking. The cells were washed with distilled water to remove unbound dye. For quantitative analysis by absorbance evaluation, nodules were solubilized with $10 \%$ cetylpyridinium chloride for 15 minutes with shaking. Absorbance was measured at $562 \mathrm{~nm}$ using Biotek Synergy HT micro plate reader [33]. The percentage increase in bone mineralization with respect to the untreated cells (baseline group) was calculated using the following equation (5):

$$
\% \text { Increase }=[(X-R) / R] * 100
$$

Where, $X=$ Absorbance in cells corresponding to positive control or test groups; $R=$ Absorbance in cells corresponding to baseline (untreated) group.

\section{Statistical analysis}

All the values were represented as percentage of respective parameters. For multiple group comparison, one-way analysis of variance (ANOVA) was used followed by post-hoc analysis by Dunnett's test. Statistically significant values were set at the level of $p \leq 0.05$.

\section{Results and Discussion}

\section{Cell viability using MTT assay}

Cell viability data showed that cell viability was significant improved percentage among the Biofield Energy Treated vitamin $\mathrm{D}_{3}$ and DMEM in MG-63 cells are shown in Figure 1. The data showed that the test samples found as nontoxic and safe (as evidence of cell viability approximately more than $71 \%$ ) across all the tested concentrations up to $100 \mu \mathrm{g} / \mathrm{mL}$. Hence, the same concentrations were used for the evaluation of other bone health parameters such as alkaline phosphatase (ALP) activity, collagen synthesis, and bone mineralization in MG-63 cells.

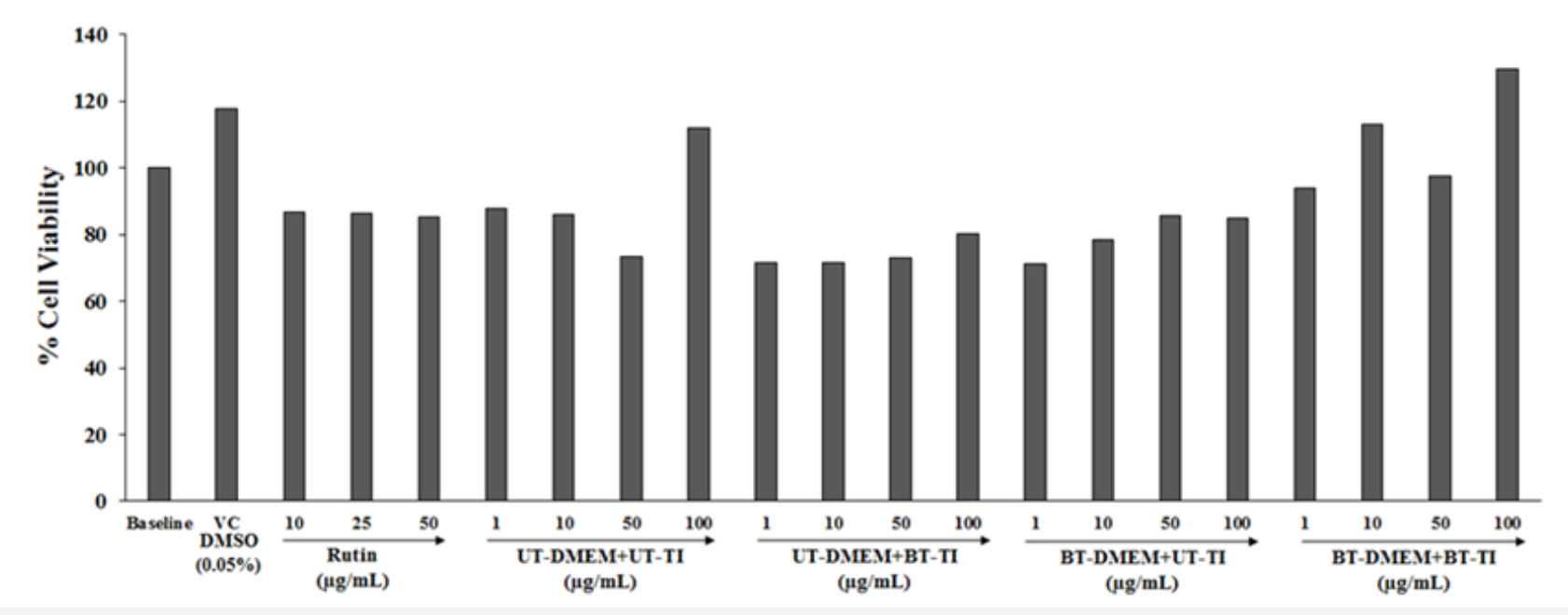

Figure 1: The effect of the test items (vitamin $D_{3}$ and DMEM medium) on cell viability in MG-63 cells after 72 hours of treatment. VC: Vehicle. 


\section{Alkaline phosphatase (ALP) enzyme activity}

The Trivedi Effect ${ }^{\circledR}$-Energy of Consciousness Healing based test items displayed an increased ALP level in various groups (Figure 2) as compared with the untreated group. The percentage change in ALP data at various concentrations in different groups were presented in Figure 2 in terms of percentage values. The positive control, rutin showed a significant increased value by $43.44 \%$, $53.55 \%$, and $83.33 \%$ at $0.01,0.1$, and $1 \mu \mathrm{g} / \mathrm{mL}$, respectively with respect to the untreated cells. The experimental test group's viz. untreated medium and Biofield Treated Test item (UT-DMEM+BTTI) showed a significant increased level of ALP by $116.4 \%$ and $2.3 \%$ at 50 and $100 \mu \mathrm{g} / \mathrm{mL}$, respectively while Biofield Treated medium and untreated Test item (BT-DMEM+UT-TI) showed a significant increased ALP level by $35.6 \%, 81.2 \%$, and $47.9 \%$ at 10 , 50 and $100 \mu \mathrm{g} / \mathrm{mL}$, respectively as compared with the untreated test item and DMEM group. However, the Biofield Energy Treated medium and Biofield Energy Treated Test item (BT-DMEM+BT-TI) showed a significant increased ALP level by $42.3 \%$ and $90.6 \%$ at 10 and $50 \mu \mathrm{g} / \mathrm{mL}$, respectively as compared with the untreated test item and DMEM group. ALP (zinc metalloprotein enzymes) is considered as one of the important bone biomarker proteins for osteoblast differentiation. Reduced level of bone ALP leads to various disorders such as obstructive liver disease, osteoblastic activity, metabolic bone disease, reduced bone growth, acromegaly, osteogenic sarcoma, or bone metastases, healing fracture, myelofibrosis, leukemia, and rarely myeloma [35-37]. Thus, the overall data suggested a significant improved ALP level after Biofield Energy Treatment. Biofield Energy Treated test samples could be useful against patients suffering from bone disorders to improve the skeletal structure and overall bone-related disorders.

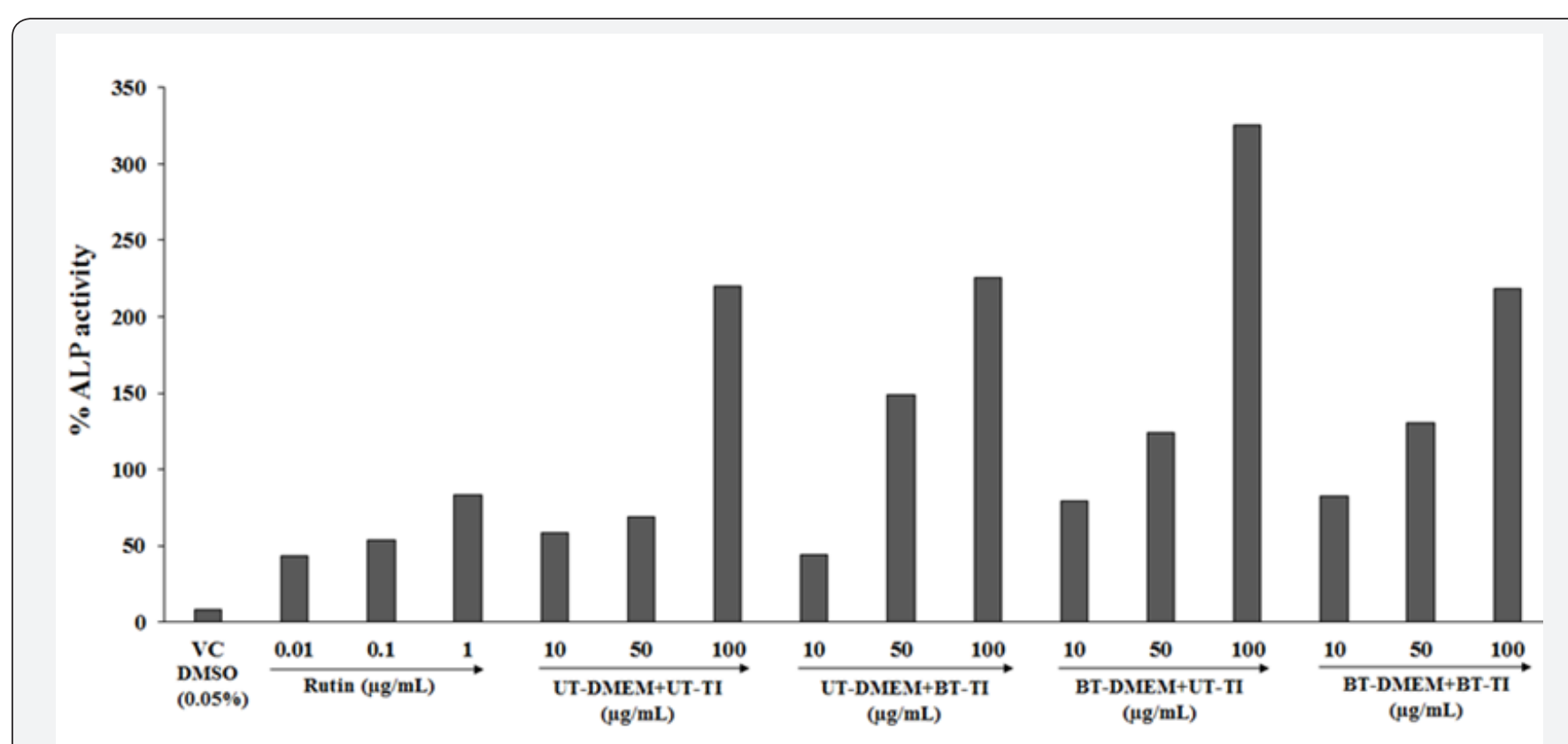

Figure 2: The study of Alkaline Phosphatase (ALP) enzyme activity of the Biofield Energy Treated test items on MG-63 cell line. VC: Vehicle control (DMSO-0.05\%), UT: Untreated; BT: Biofield Treated; TI: Test Item.

\section{Estimation of collagen synthesis}

The Trivedi Effect ${ }^{\circledR}$-Biofield Energy Treated test samples showed a significant enhanced level of collagen synthesis as compared with the untreated test samples. All the results are presented in percentage collagen values in Figure 3. The rutin hydrate (positive control group) showed a significant increased value of collagen by $46.59 \%, 51.97 \%$, and $65.41 \%$ at $0.01,0.1$, and $1 \mu \mathrm{g} /$ $\mathrm{mL}$, respectively. In addition, the experimental test groups such as UT-DMEM+BT-TI showed a significant increased collagen level by $10.5 \%$ and $110.1 \%$ at 0.1 and $1 \mu \mathrm{g} / \mathrm{mL}$, respectively while BTDMEM+UT-TI group showed a significant increased collagen level by $22.6 \%, 190.6 \%$, and $1.6 \%$ at $0.1,1$, and $10 \mu \mathrm{g} / \mathrm{mL}$, respectively as compared with the untreated test item and DMEM group. On the other hand, BT-DMEM+BT-TI group showed a significant increased collagen level by $140.6 \%$ and $39.9 \%$ at 0.1 and $1 \mu \mathrm{g} / \mathrm{mL}$, respectively as compared with the untreated test item and DMEM group. Collagen synthesis leads to build stronger bone and muscles, which provide strength to skeletal structure. Collagen fibers provide strong mechanical force and strength to life. The most abundant matrix protein, collagen type I play a significant role in overall bone health [38,39]. Overall, the Consciousness Energy treated vitamin $\mathrm{D}_{3}$ had significantly improved the synthesis of collagen fibers in the human osteosarcoma cells with respect to all the treatment groups. Hence, it is assumed that The Trivedi Effect ${ }^{\circledR}$ has the significant potential to improve the bone health in various skeletal disorders against weaken joints, tendons, and ligaments. 


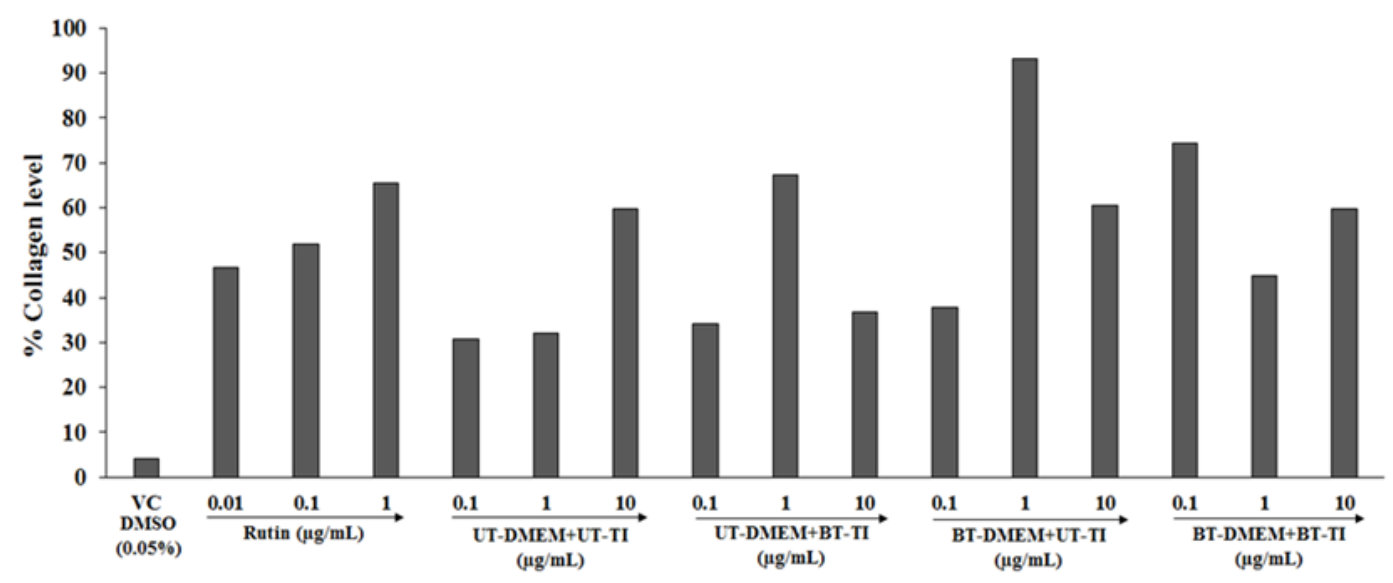

Figure 3: The effect of the test item on MG-63 cell line for collagen level. VC: Vehicle control (DMSO-0.05\%), UT: Untreated; BT: Biofield Treated; TI: Test Item.

\section{Bone mineralization}

The effect of Biofield Energy Treatment (Trivedi Effect ${ }^{\circledR}$-Biofield Energy Healing) on bone mineralization in MG-63 cells is shown in Figure 4, which showed a significant increased bone mineralization percentage in the test samples. Supplementation with calcium and vitamin $\mathrm{D}_{3}$ increased the chance of degree of bone mineralization. As, bioactive vitamin $\mathrm{D}$ or calcitriol is a steroid hormone, which has an important long term role in regulating the body levels of calcium and phosphorus, and in bone mineralization process. However, lack of vitamin D and calcium is directly linked to an inability of any person to fight against infections effectively, depression, muscle weakness, multiple sclerosis, fatigue and the development of diabetes, bone cancers, heart disease, high blood pressure, and stroke $[40,41]$. The results in term of percentage bone mineralization was presented in Figure 4. The positive control, rutin group showed a significant increased value of bone mineralization by $47.98 \%, 59.73 \%$, and $139.02 \%$ at 5,10 , and $25 \mu \mathrm{g} / \mathrm{mL}$, respectively. The experimental data among test group's viz. UT-DMEM+BT-TI showed a significant increased bone mineralization by $128.7 \%$ at $50 \mu \mathrm{g} / \mathrm{mL}$, while BT-DMEM+UTTI group showed a significantly increased bone mineralization by $34.1 \%, 154.7 \%$, and $18.7 \%$ at 1,10 , and $50 \mu \mathrm{g} / \mathrm{mL}$, respectively as compared with the untreated test item and DMEM group. However, BT-DMEM+BT-TI group showed a significant increased bone mineralization by $105.7 \%, 78.1 \%$, and $39.6 \%$ at 1,10 , and $50 \mu \mathrm{g} /$ $\mathrm{mL}$, respectively as compared with the untreated test item and DMEM group. Thus, The Trivedi Effect ${ }^{\circledR}$-Biofield Energy Treated vit $\mathrm{D}_{3}$ could be significantly useful to maintain a healthy skeletal structure for the patients suffering from various bone-related disorders.

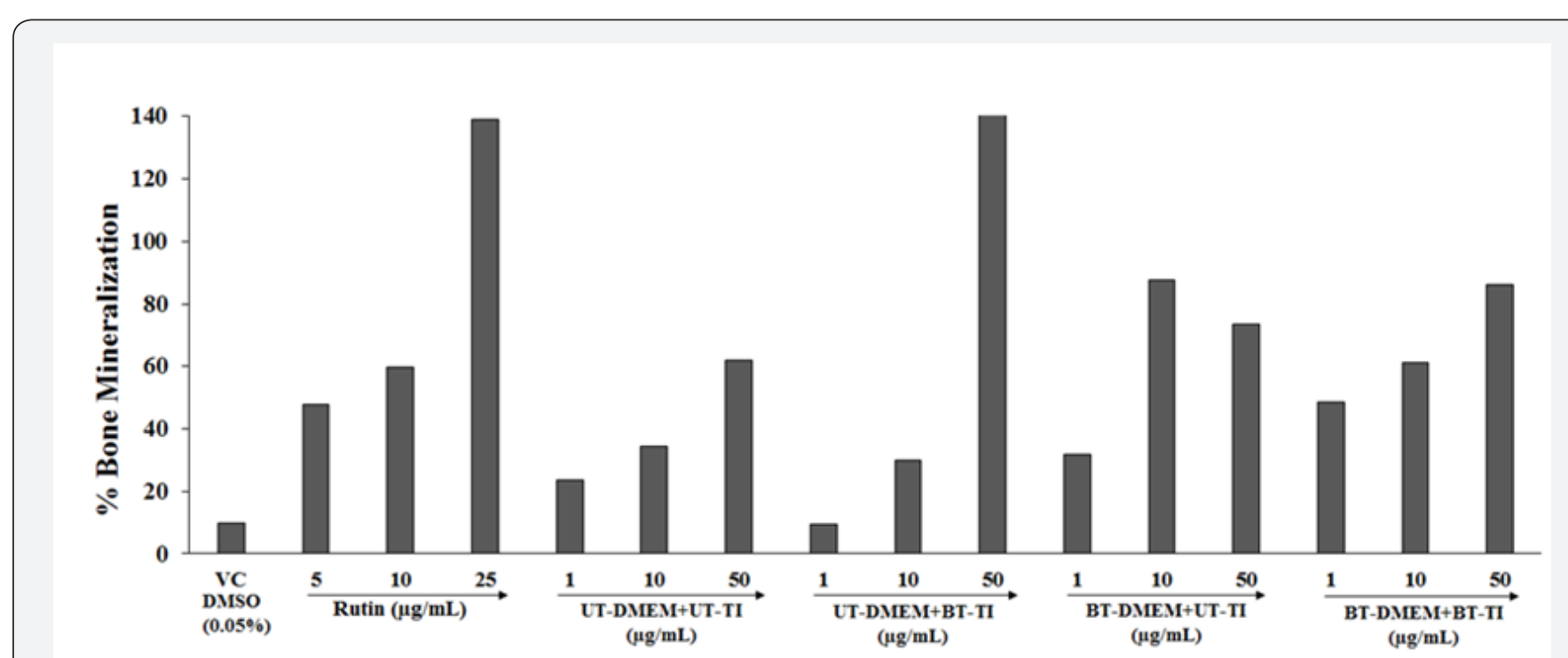

Figure 4: The effect of Biofield Energy Treatment on the test item for bone mineralization using MG-63 cell line. VC: Vehicle control (DMSO-0.05\%), UT: Untreated; BT: Biofield Treated; TI: Test Item. 


\section{Conclusion}

The experimental results of cell viability data using MTT assay showed more than $71 \%$ cells were viable and Consciousness Energy Healing based vitamin $\mathrm{D}_{3}$ further improved the cell viability. Thus, MTT data indicated that the test samples were safe and nontoxic in all the tested concentrations. However, various bone health parameters were significantly improved such as ALP was increased by $116.4 \%$ at $50 \mu \mathrm{g} / \mathrm{mL}$ in the UT-DMEM+BT-TI, while $35.6 \%, 81.2 \%$, and $47.9 \%$ at 10,50 and $100 \mu \mathrm{g} / \mathrm{mL}$, respectively in the BT-DMEM+UT-TI group as compared with the untreated test item and DMEM group. In addition, BT-DMEM+BT-TI group showed an increased ALP level by $42.3 \%$ and $90.6 \%$ at 10 and $50 \mu \mathrm{g} / \mathrm{mL}$, respectively. The level of collagen was significantly increased by $10.5 \%$ and $110.1 \%$ at 0.1 and $1 \mu \mathrm{g} / \mathrm{mL}$, respectively in the UT-DMEM+BT-TI, while $22.6 \%, 190.6 \%$, and $1.6 \%$ at $0.1,1$, and $10 \mu \mathrm{g} / \mathrm{mL}$, respectively in the BT-DMEM+UT-TI group. The level of collagen was increased by $140.6 \%$ and $39.9 \%$ at 0.1 and $1 \mu \mathrm{g} / \mathrm{mL}$, respectively in BT-DMEM+BT-TI group as compared with the untreated test item and DMEM group. Similarly, the bone mineralization percent was significantly increased by $128.7 \%$ at $550 \mu \mathrm{g} / \mathrm{mL}$ in the UT-DMEM+BT-TI group, while $34.1 \%, 154.7 \%$, and $18.7 \%$ at 1,10 , and $50 \mu \mathrm{g} / \mathrm{mL}$, respectively in the BT-DMEM+UT-TI group as compared with the untreated group. In addition, BT-DMEM+BTTI group showed a significant increased bone mineralization by $105.7 \%, 78.1 \%$, and $39.6 \%$ at 1,10 , and $50 \mu \mathrm{g} / \mathrm{mL}$, respectively as compared with the untreated group. The Bone health parameters were significantly improved among the Biofield Energy Treated vitamin $D_{3}$ test samples in MG-63 cells. Overall, the Biofield Energy Treated (The Trivedi Effect ${ }^{\circledR}$ ) test samples were found to have a significant impact on tested bone health parameters viz. collagen, bone mineralization, and ALP, which are very vital to combat the bone disorders. Therefore, the Consciousness Energy Healing based vitamin $D_{3}$ might be a suitable alternative nutritional supplement, which could be useful for the management of various bone related disorders viz. osteoporosis, Paget's disease of bone, rickets, deformed bones, osteomalacia, bone and/or joint pain, increased frequency of fractures, osteoma, hormonal imbalance, stress, aging, bone loss and fractures, and other bone diseases that are caused by poor nutrition, genetics, or problems with the rate of bone growth or rebuilding. Biofield Energy Treated Vitamin $\mathrm{D}_{3}$ can be useful as anti-inflammatory, anti-aging, anti-stress, anti-arthritic, anti-osteoporosis, anti-cancer, anti-apoptotic, wound healing, anti-psychotic and anti-fibrotic roles. It also influence cell-to-cell communication, normal cell growth, cell differentiation, neurotransmission, cell cycling and proliferation, hormonal balance, skin health, immune and cardiovascular functions. Besides, it can also be utilized in hormonal imbalance, aging, and various immune related disease conditions such as Multiple Sclerosis, Alzheimer's Disease, Asthma, Atherosclerosis, Pernicious Anemia, Aplastic Anemia, Diverticulitis, Graves' Disease, Dermatomyositis, Dermatitis, stress, Irritable Bowel Syndrome, Systemic Lupus Erythematosus, Hepatitis, Hashimoto Thyroiditis,Diabetes, Myasthenia Gravis, Ulcerative Colitis, Sjogren Syndrome, Parkinson's Dis- ease, etc. with a safe therapeutic index to improve overall health, and quality of life.

\section{Acknowledgement}

Authors are grateful to Dabur Research Foundation, Trivedi Global, Inc., Trivedi Science, Trivedi Testimonials, and Trivedi Master Wellness for their support throughout the work.

\section{References}

1. Holick MF (1996) Vitamin D and bone health. J Nutr 126(4 Suppl): 1159S-1164S.

2. Van Leeuwen JP, van Driel M, van den Bemd GJ, Pols HA (2001) Vitamin D control of osteoblast function and bone extracellular matrix mineralization. Crit Rev Eukaryot Gene Expr 11(1-3): 199-226.

3. Bikle DD (2012) Vitamin D and bone. Curr Osteoporos Rep 10(2): 151159.

4. Lips P (2001) Vitamin D deficiency and secondary hyperparathyroidism in the elderly: consequences for bone loss and fractures and therapeutic implications. Endocr Rev 22(4): 477-501.

5. Hossein-nezhad A, Holick MF (2013) Vitamin D for health: A global perspective. Mayo Clin proc 88(7): 720-755.

6. Czekanska EM, Stoddart MJ, Richards RG, Hayes JS (2012) In search of an osteoblast cell model for in vitro research. Eur Cell Mater 24: 1-17.

7. Luo XH, Liao EY (2003) Effects of estriol on the proliferation and differentiation of human osteoblastic MG-63 cells. Endocr Res 29(3): 343-351.

8. Iba K, Takada J, Yamashita T (2004) The serum level of bone-specific alkaline phosphatase activity is associated with aortic calcification in osteoporosis patients. J Bone Miner Metab 22(6): 594-596.

9. Viguet-Carrin S, Garnero P, Delmas PD (2006) The role of collagen in bone strength. Osteoporos Int 17(3): 319-336.

10. Bhattarai T, Bhattacharya K, Chaudhuri P, Sengupta P (2014) Correlation of common biochemical markers for bone turnover, serum calcium, and alkaline phosphatase in post-menopausal women. Malays J Med Sci 21(1): 58-61.

11. Rubik B (2002) The biofield hypothesis: Its biophysical basis and role in medicine. J Altern Complement Med 8(6): 703-717.

12. Barnes PM, Bloom B, Nahin RL (2008) Complementary and alternative medicine use among adults and children: United States, 2007. Natl Health Stat Report 12: 1-23.

13. Frass M, Strassl RP, Friehs H, Müllner M, Kundi M, et al. (2012) Use and acceptance of complementary and alternative medicine among the general population and medical personnel: A Systematic Review. Ochsner J 12(1): 45-56.

14. Trivedi MK, Tallapragada RM (2008) A transcendental to changing metal powder characteristics. Met Powder Rep 63(9): 22-28, 31.

15. Trivedi MK, Nayak G, Patil S, Tallapragada RM, Latiyal O (2015) Studies of the atomic and crystalline characteristics of ceramic oxide nano powders after bio field treatment. Ind Eng Manage 4: 161.

16. Trivedi MK, Nayak G, Patil S, Tallapragada RM, Latiyal O, et al. (2015) Effect of biofield energy treatment on physical and structural properties of calcium carbide and praseodymium oxide. International Journal of Materials Science and Applications 4(6): 390-395.

17. Trivedi MK, Branton A, Trivedi D, Nayak G, Mondal SC, et al. (2015) Morphological characterization, quality, yield and DNA fingerprinting of biofield energy treated alphonso mango (Mangifera indica L.). Journal of Food and Nutrition Sciences 3(6): 245-250. 
18. Trivedi MK, Branton A, Trivedi D, Nayak G, Mondal SC, et al. (2015) Evaluation of biochemical marker - Glutathione and DNA fingerprinting of biofield energy treated Oryza sativa. American Journal of BioScience 3(6): 243-248.

19. Trivedi MK, Branton A, Trivedi D, Nayak G, Charan S, et al. (2015) Phenotyping and 16S rDNA analysis after biofield treatment on Citrobacter braakii: A urinary pathogen. J Clin Med Genom 3: 129.

20. Trivedi MK, Patil S, Shettigar H, Mondal SC, Jana S (2015) Evaluation of biofield modality on viral load of Hepatitis B and C viruses. J Antivir Antiretrovir 7: 083-088.

21. Ansari SA, Trivedi MK, Branton A, Trivedi D, Nayak G, et al. (2018) In vitro effects of biofield energy treated vitamin $\mathrm{D}_{3}$ supplementation on bone formation by osteoblasts cells. Biomedical Sciences 4(1): 10-17.

22. Koster DA, Trivedi MK, Branton A, Trivedi D, Nayak G, et al. (2018) Evaluation of biofield energy treated vitamin $D_{3}$ on bone health parameters in human bone osteosarcoma cells (MG-63). Biochemistry and Molecular Biology 3(1): 6-14.

23. Nayak G, Altekar N (2015) Effect of biofield treatment on plant growth and adaptation. J Environ Health Sci 1: 1-9.

24. Branton A, Jana S (2017) The influence of energy of consciousness healing treatment on low bioavailable resveratrol in male Sprague Dawley rats. International Journal of Clinical and Developmental Anatomy 3(3): 9-15.

25. Branton A, Jana S (2017) The use of novel and unique biofield energy healing treatment for the improvement of poorly bioavailable compound, berberine in male Sprague Dawley rats. American Journal of Clinical and Experimental Medicine 5(4): 138-144.

26. Branton A, Jana S (2017) Effect of The biofield energy healing treatment on the pharmacokinetics of 25-hydroxyvitamin $\mathrm{D}_{3}[25(\mathrm{OH})$ $\left.\mathrm{D}_{3}\right]$ in rats after a single oral dose of vitamin D3. American Journal of Pharmacology and Phytotherapy 2(1): 11-18.

27. Kinney JP, Trivedi MK, Branton A, Trivedi D, Nayak G, et al. (2017) Overall skin health potential of the biofield energy healing based herbomineral formulation using various skin parameters. American Journal of Life Sciences 5(2): 65-74.

28. Singh J, Trivedi MK, Branton A, Trivedi D, Nayak G, et al. (2017) Consciousness energy healing treatment based herbomineral formulation: A safe and effective approach for skin health. American Journal of Pharmacology and Phytotherapy 2(1): 1-10.
29. Trivedi MK, Branton A, Trivedi D, Nayak G, Plikerd WD, et al. (2017) A Systematic study of the biofield energy healing treatment on physicochemical, thermal, structural, and behavioral properties of magnesium gluconate. International Journal of Bioorganic Chemistry 2(3): 135-145.

30. Trivedi MK, Branton A, Trivedi D, Nayak G, Plikerd WD, et al (2017) Chromatographic and spectroscopic characterization of the consciousness energy healing treated Withania Somnifera (ashwagandha) root extract. European Journal of Biophysics 5(2): 3847.

31. Trivedi MK, Patil S, Shettigar H, Mondal SC, Jana S (2015) The potential impact of biofield treatment on human brain tumor cells: A time-lapse video microscopy. J Integr Oncol 4(3): 141.

32. Trivedi MK, Patil S, Shettigar H, Gangwar M, Jana S (2015) In vitro evaluation of biofield treatment on cancer biomarkers involved in endometrial and prostate cancer cell lines. J Cancer Sci Ther 7: 253257.

33. Czekanska EM, Stoddart MJ, Richards RG, Hayes JS (2012) In search of an osteoblast cell model for in vitro research. Eur Cells Mater 24: 1-17.

34. Biological evaluation of medical devices - Part 5: Tests for in vitro cytotoxicity (ISO 10993-5:2009), I.S.EN ISO, 10993-5:20093.

35. Saraç F, Saygllı F (2014) Causes of high bone alkaline phosphatase. Biotechnol Biotechnol Equip 21(2): 194-197.

36. Kubo K, Yuki K, Ikebukuro T (2012) Changes in bone alkaline phosphatase and procollagen type-1 C-peptide after static and dynamic exercises. Res Q Exerc Sport 83(1): 49-54.

37. Deftos LJ, Wolfert RL, Hill CS (1991) Bone alkaline phosphatase in Paget's disease. Horm Metab Res 23(11): 559-561.

38. Barnes MJ, Constable BJ, Morton LF, Kodicek E (1973) Bone collagen metabolism in vitamin D deficiency (Short Communication). Biochem J 132: 113-115.

39. Bringhurst FR, Potts JT (1982) Effects of vitamin D metabolites and analogs on bone collagen synthesis in vitro. Calcif Tissue Int 34(1): 103-110.

40. Ruppel ME, Miller LM, Burr DB (2008) The effect of the microscopic and nanoscale structure on bone fragility. Osteoporos Int 19(9): 12511265 .

41. van Driel M, van Leeuwen JPTM (2017) Vitamin D endocrinology of bone mineralization. Mol Cell Endocrinol 453: 46-51.

\section{Your next submission with Juniper Publishers will reach you the below assets}

- Quality Editorial service

- Swift Peer Review

- Reprints availability

- E-prints Service

- Manuscript Podcast for convenient understanding

- Global attainment for your research

- Manuscript accessibility in different formats

( Pdf, E-pub, Full Text, Audio)

- Unceasing customer service

Track the below URL for one-step submission https://juniperpublishers.com/online-submission.php 